\title{
MIGRATION OF AMPHIBIANS AND THEIR MORTALITY ON THE ROAD OF KNYSZYN FOREST LANDSCAPE PARK
}

\begin{abstract}
Spring migration and mortality of two common amphibian species on the road in one of the landscape parks in north-eastern Poland (Knyszyn Forest Landscpae Park) were studied in the years 2013-2015. During three years of the study, total number of 2745 individuals classified to 7 different species and one amphibian group were transfered through the road. The most popular species caught into the traps were: common toad, smooth newt and the common frog.

Mortality of two studied amphibian species (Bufo bufo and Rana temporaria) dropped over three years of the study. There were positive significant correlation between temperature and the number of migrating amphibians on the road.
\end{abstract}

Keywords: amphifauna, migration, road mortality, Poland, Knyszyn Forest

\section{Introduction}

In the modern world it is believed that amphibians are one of the groups with the highest risk of extinction due to continuous changes of the surrounding environ-

\footnotetext{
* Knyszyn Forest Landscape Park, Chodakowskiego 6, 16-030 Suprasl, Poland, e-mail: maciek1985-22@tlen.pl
} 
ment (Wake, Vredenburg 2008; Hamer, McDonell 2008). Data on the number of amphibians species showed that annually comes to the disappearance from one to several species from the world map of animals. One of the key factors causing decline in amphibian populations in the world but also in Poland is the development of transport infrastructure, expansion of existing roads, new transport links (Glista et al. 2008; Elzanowski et al. 2009). This rapid growth of local road infrastructure is often associated with the formation of different kinds of ecological barriers, which causes fragmentation of habitats and genetic isolation between populations of animals (Andrews et al. 2008).

The first observations on the spring migration of amphibians on the roads in our country come from the area of the Bialowieza Forest from the late 70s of XX century (Wołk 1978). In the available literature there is no information about migration and mortality of amphibians on the roads located in the area of Knyszyn Forest Landscape Park (PKPK). This fact prompted us to attempt to determine the scale of this phenomenon in this region of north-east part of Poland.

The purpose of this study was to describe the composition of amphibian species during the spring migration on the section of the local road Zapieczki - Studzian$\mathrm{ki}$ in the years 2013-2015 located in the center area of Park. We also attempted to determine the mortality rates of two amphibian species (common toad - Bufo bufo and common frog - Rana temporaria) on the selected section of the road and investigate the effect of weather conditions (air temperature conditions, humidity, rainfall, wind direction) on the number of migrating amphibians.

\section{Materials and methods}

The study area covered the part of local road located in Knyszyn Forest Landscape Park near the village Studzianki (Figs. 1-2). The place was under our investigation as a result of an earlier observation of increased intensity migration of amphibians to water reservoirs situated near the local road in the spring months (march-april). Breeding water reservoirs were located only in the one site of the road (on the west - near the houses). The research methodology include a setting of protective barriers on both sides of the road in a distance of $400 \mathrm{~m}$. Barriers have been installed for 3 to 4 weeks in each calendar year. Along the barriers (every $100 \mathrm{~m}$ ), plastic traps were burried, where the amphibians fell. Barriers were placed only in one side of the road. In each barrier there were two breaks (roads to the agriculture pool) were amphibians crosed the road and were killed 


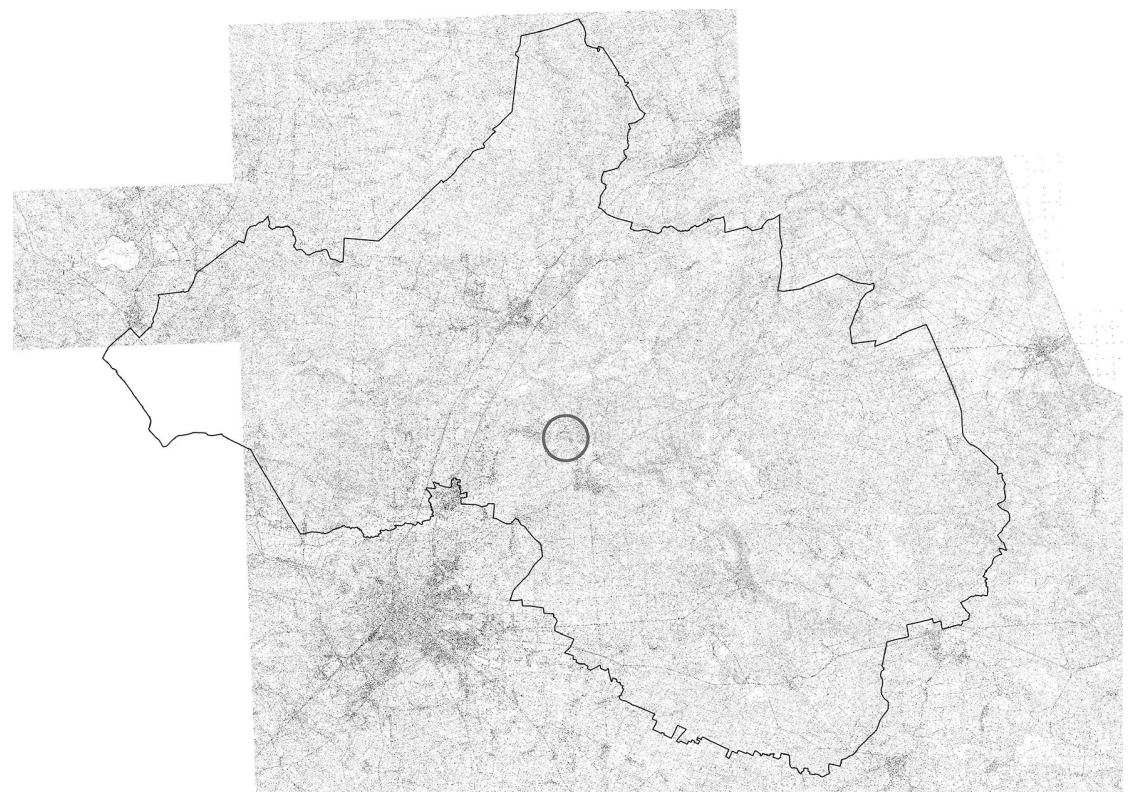

Figure 1. Location of the study area (red circle) within the Knyszyn Forest Landscape Park

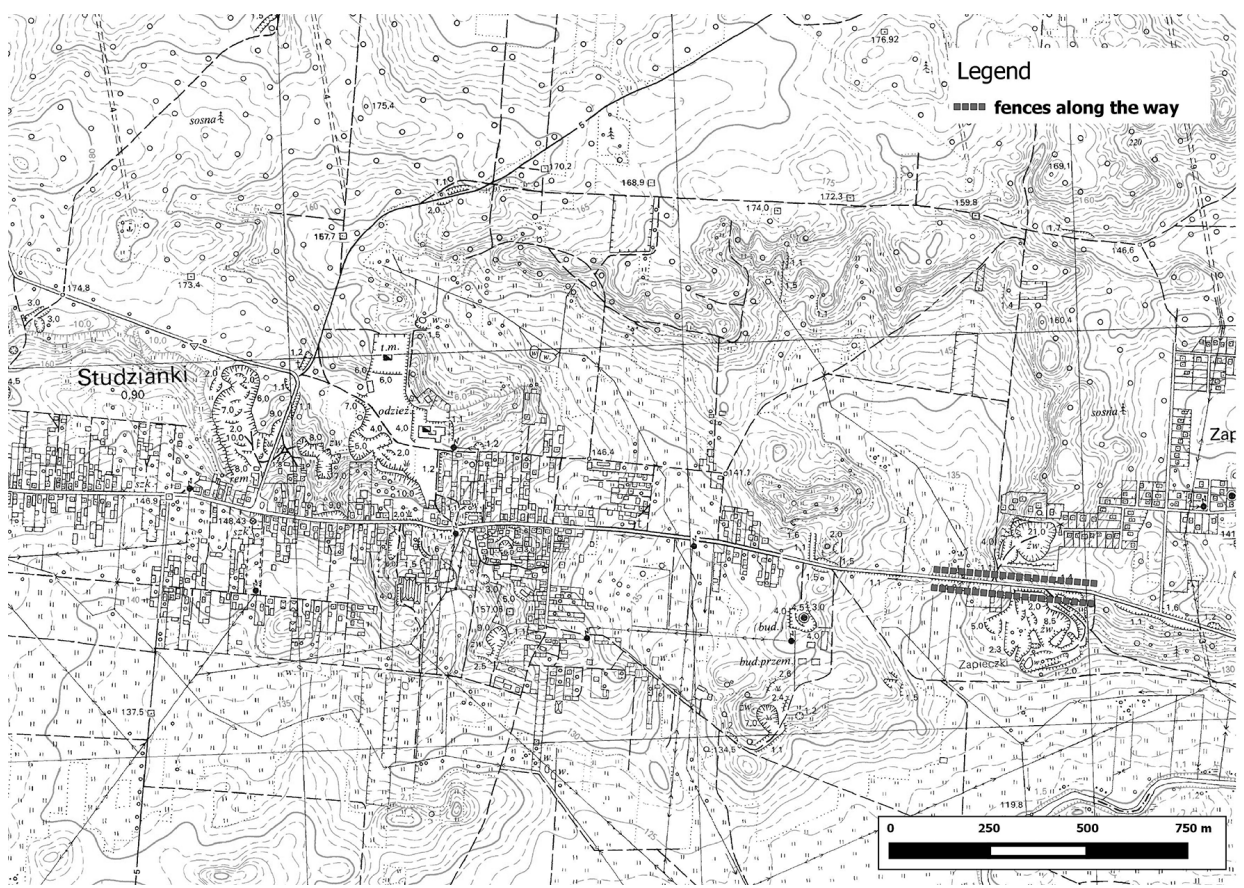

Figure 2. Localization of fences on the road in Studzianki 
by the local cars. During two or three visits per day amphibians found in a trap were measured and weighted. Also their sex and species affiliation were determined. After completing the measurements, amphibians were transferred safely to the other side of the road. Percentage of each amphibian species was calculated as a ratio of adults aphmibians of the specie to the total number of all live amphibians transfered threw the road during the season (Tab. 1).

Table 1. The number and percentage of particular amphibian species observed during spring migrations in the Knyszyn Forest Landscape Park

\begin{tabular}{|l|c|c|c|c|}
\hline \multicolumn{1}{|c|}{ Species } & 2013 & 2014 & 2015 & $\begin{array}{c}\text { Percentege of the species } \\
{[\%]}\end{array}$ \\
\hline $\begin{array}{l}\text { Common frog } \\
\text { Rana temporaria }\end{array}$ & 8 & 180 & 31 & 8,0 \\
\hline $\begin{array}{l}\text { Common toad } \\
\text { Bufo bufo }\end{array}$ & 577 & 821 & 694 & 76,2 \\
\hline $\begin{array}{l}\text { Moor frog } \\
\text { Rana arvalis }\end{array}$ & 10 & 20 & 27 & 2,1 \\
\hline $\begin{array}{l}\text { Green frogs } \\
\text { Pelophylax esculentus complex }\end{array}$ & 17 & 22 & 0 & 1,4 \\
\hline $\begin{array}{l}\text { Spadefoot toad } \\
\text { Pelobates fuscus }\end{array}$ & 19 & 7 & 8 & 0,3 \\
\hline $\begin{array}{l}\text { Fire-bellied toad } \\
\text { Bombina bombina }\end{array}$ & 2 & 2 & 5 & 10,7 \\
\hline $\begin{array}{l}\text { Smooth newt } \\
\text { Lissotriton vulgaris }\end{array}$ & 139 & 83 & 71 & 0,1 \\
\hline $\begin{array}{l}\text { Warty newt } \\
\text { Triturus cristatus }\end{array}$ & 0 & 0 & 2 & 100 \\
\hline Total & 772 & 1135 & 838 & 1,2 \\
\hline
\end{tabular}

In addition we also calculate percentage of dead animals (M parameter) for the two common species of amphibians: Bufo bufo and Rana temporaria on the section of the investigated road:

$$
\mathbf{M}=(\mathbf{L m} / \mathbf{L w}) \times \mathbf{1 0 0 \%} \text { where, }
$$

$\mathbf{L} \mathbf{m}$ - the number of dead individuals of species, $\mathbf{L w}$ - the number of all individuals of this species (living and dead).

During the study in the 2015, we decided also to record weather conditions on each day in the village Studzianki (meteorological data). During the analysis we decided to try to determinate the presence of correlation between air temperature, humidity, rainfall, wind direction and the number of migrating amphibians. Statisitical analysis was performed using STATISTICA software 10.0 PL. 
We obtained a special permission for the capture and transfer of amphibians from the Regional Director for Environmental Protection in Białystok (WPN.6401.47.2015.MW).

\section{Results}

During the three years of the study we have found 2745 individuals belonging to seven species of lowland amphibians (Tab. 1). These were: smooth newt - Lissotriton vulgaris, warty newt - Triturus cristatus, common toad - Bufo bufo, common frog - Rana temporaria, moor frog - Rana arvalis, fire-bellied toad Bombina bombina and spadefoot toad - Pelobates fuscus and one complex of green frogs - Pelophylax esculentus complex, which include two species: pool frog - Pelophylax lessonae and edible frog - Pelophylax esculentus.

The most commonly amphibian species found in buckets during spring migration were: common toad $(\mathrm{N}=2092 ; 76.2 \%)$, smooth newt $(\mathrm{N}=293 ; 10.7 \%)$ and the common frog $(\mathrm{N}=219 ; 8 \%)$. The participation of other species was small and was from 0,1 to $2,1 \%$ (Tab. 1 ).

The mortality rate in the analyzed two amphibian species decline from one year to another. Mortality of Bufo bufo on the road dropped from $25 \%$ to $12 \%$, while for Rana temporaria tested parameter has decreased from $10 \%$ to $8 \%$ (Fig. 3).

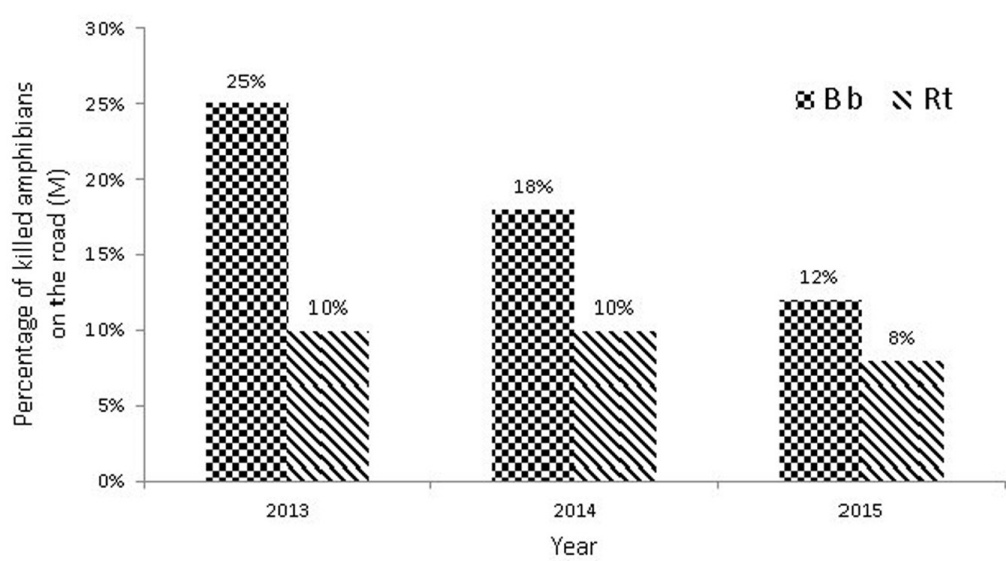

Figure 3. The mortality rate $(\mathrm{M})$ of common toad $(\mathrm{Bb})$ and common frog $(\mathrm{Rt})$ on the road in Studzianki from 2013 to 2015 
The results of the statistical analysis showed only one statistically significant correlation between studied meteorological parameters. We observed positive correlation between air temperature and the number of migrating amphibians $r=0.52, p=0.0065$. In case of other parameters we could not confirm the existence of any statistically significant dependence (Tab. 2).

Table 2. The values of correlation coefficients between the studied meteorological parameters and the number of amphibians during migration

\begin{tabular}{|l|c|c|}
\hline \multicolumn{1}{|c|}{ Weather parameter } & Pearson parameter $(\mathrm{r})$ & P value \\
\hline Air temperature $\left[{ }^{\circ} \mathrm{C}\right]$ & 0,52 & 0.0065 \\
\hline Humidity [\%] & -0.33 & 0.066 \\
\hline Rainfall [mm] & -0.26 & 0.1225 \\
\hline Wind direction & 0.049 & 0.4145 \\
\hline
\end{tabular}

\section{Discussion}

During the three years of amphibian monitoring in Studzianki we managed to move 2745 individuals classified into 7 species and one complex of green frogs Pelophylax esculentus complex. Our observation about composition of amphibians species migrating through the roads are consistent with available literature data regarding our country (Sołtysiak, Motyka 2004; Puky 2003; Gryz, Krauze 2008).

By studying the migration of amphibians on the selected section of a local road in PKPK, in 2015 we found for the first time the presence of warty newt Triturus cristatus (new location of this species at the Park). It is quite important because in Poland, only Sołtysiak and Rybacki (2010) reported population of this amphibian migrating across the road in the area of Grodziec Silesia.

Furthermorer in our the study we also found the second valuable species of amphibians - fire-bellied toad (Bombina bombina). According to literature data population of this animal is less abundant in our country as same as Triturus cristatus (Głowaciński, Rafiński 2003). So far in the literature there is only few articles about migration of fire-bellied toad (Kovar et al. 2009; Hartel 2008). Available literature data indicate that the roads are in many cases for this species a kind 
of barrier that impedes the free mixing between the populations of amphibians individuals (Andrews et al. 2008).

Construction of new connections as well as the reconstruction of existing roads makes separation of natural migration corridors for animals (Forman, Alexander 1998). Consequently, there is an increase in mortality of animals, including amphibians on roads and in their vicinity (Hels, Buchwald 2001; Glista et al. 2008). In our study we investigate road mortality of two common lowland amphibian species - Bufo bufo and Rana temporaria. During three years of the study we observed mostly common toad and common frog killed on the part of the road. This observation is consistent with the available literature data (Elzanowski et al. 2009; Błażuk 2010). The dominance of dead individuals of Bufo bufo stems from the fact that it is common species in our country but is also a species taking mass migration during the breeding season (Juszczyk 1974). Likewise common frog belongs to a species with less marked tendency to migration compared to the common toad. Less mortality of this species on the road is also apparent from the fact that the majority of individuals of this species stays for winter in various types of water bodies in which accede to reproduction (Barton, Rafiński 2006).

Some articles suggest that daily activity and migration of many organisms is dependent of weather conditions and the phases of the moon (Brown, Shine 2002; Miller-Rushing et al. 2008; Grant et al. 2012). In the literature, there is no specific information indicating that the weather affect the activity and reproduction of amphibians in our country. In our study we demonstrated that increased activity of amphibians migration was linked with higher air temperature prevailing in Studzianki. A similar observation, however on snakes in tropical forests showed Brown and Shine (2002). Moreover we have shown that the number of migrating amphibians negatively correlated with the level of humidity. No available literature data can confirm our observation. Only some unpublished data from Narew National Park shows that air temperature correlates positively and humidity negatively with the number of migration amphibians, which is in agreement with our observation. Interesting results are the effects of Grant et al. (2008) paper, which shows a positive effect on the amphibians migration activity of the phases of the moon. It is worth to look at the impact of this factor in the subsequent years of the shares on the migration of amphibians in our location.

Given the fact that amphibians belong to the group of animals highly responsive to all kinds of environmental changes, each work about their biology and 
ecology given us something new to learn about them. In the following years we intend to continue undertaken observations, expanding the range of our activities.

\section{References}

Andrews K.M., Gibbons J.W., Jochimsen D.M. 2008. Ecological effects of roads on amphibians and reptiles: A literature review. Urban Herpetology, 3: 121-143.

Barton K., Rafinski J. 2006. Co-occurrence of agile frog (Rana dalmatina Fitz. in Bonaparte) with common frog (Rana temporaria L.) in breeding sites in southern Poland. Polish Journal of Ecology, 54: 151-157.

Błażuk J. 2010. Obserwacje martwych płazów i gadów na drogach w dolinie Sanu pod Otrytem i terenach przyległych. Wszechświat, 11: 144-146.

Brown G.P., Shine R. 2002. Influence of weather conditions on activity of tropical snakes. Austral Ecology, 27: 596-605.

Elzanowski A., Ciesiołkiewicz J., Kaczor M., Radwańska J., Urban R. 2009. Amphibian road mortality in Europe: a meta-analysis with new data from Poland. European Journal of Wildlife Research, 55: 33-43.

Forman R.T., Alexander L.E. 1998. Roads and their major ecological effects. Annual Review of Ecology and Systematics, 29: 207-231.

Glista D.J., Devault T.L., DeWoody J.A. 2008. Vertebrate road mortality predominantly impacts amphibians. Herpetological Conservation and Biology, 3: 77-87.

Głowaciński Z., Rafiński J. 2003. Atlas płazów i gadów Polski. Status - rozmieszczenie ochrona. GIOŚ, Warszawa.

Grant R., Halliday T., Chadwick E. 2012. Amphibians' response to the lunar synodic cycle - a review of current knowledge, recommendations, and implications for conservation. Behavioral Ecology, ars135.

Gryz J., Krauze D. 2008. Mortality of vertebrates on a road crossing the Biebrza Valley (NE Poland). European Journal of Wildlife Research, 54: 709-714.

Hamer A.J., McDonnell M.J. 2008. Amphibian ecology and conservation in the urbanising world: a review. Biological Conservation, 141: 2432-2449.

Hartel T. 2008. Movement activity in a Bombina variegata population from a deciduous forested landscape. North-Western Journal of Zoology, 4: 79-90.

Hels T., Buchwald E. 2001. The effect of road kills on amphibian populations. Biological Conservation, 99: 331-340.

Juszczyk W. 1974. Płazy i gady krajowe. PWN, Warszawa.

Kovar R., Brabec M., Vita R., Bocek R. 2009. Spring migration distances of some Central European amphibian species. Amphibia-Reptilia, 30: 367-378. 
Miller-Rushing A.J., Lloyd-Evans T.L., Primack R.B., Satzinger P. 2008. Bird migration times, climate change, and changing population sizes. Global Change Biology, 14: 1959-1972.

Puky M. 2003. Amphibian mitigation measures in central-Europe. Ecotoxicology Lead Campus Program, 11: 413-429.

Sołtysiak M., Motyka L. 2004. Monitoring wczesnowiosennych migracji godowych płazów w 2004 r. w rejonie Planetarium Śląskiego w Chorzowie. Biologia płazów i gadów. Materiały pokonferencyjne, VII Ogólnopolska Konferencja Herpetologiczna, pp.117-122.

Sołtysiak M., Rybacki M. 2010. Złe praktyki w opracowaniu i opiniowaniu raportów oceny oddziaływania na środowisko $w$ zakresie herpetologii przy inwestycjach drogowych na przykładzie obwodnicy Grodźca Śląskiego (województwo śląskie). Materiały pokonferencyjne, X Ogólnopolska Konferencja Herpetologiczna, pp. $150-156$.

Wake D.B., Vredenburg V.T. 2008. Are we in the midst of the sixth mass extinction? A view from the world of amphibians. Proceedings of the National Academy of Sciences of the United States of America, 105: 11466-11473.

Wołk K. 1978. Zabijanie zwierząt przez pojazdy samochodowe w Rezerwacie Krajobrazowym Puszczy Białowieskiej. Chrońmy Przyrodę Ojczysta, 34: 20-28. 


\section{MIGRACJA PLAZÓW ORAZ ICH ŚMIERTELNOŚĆ NA LOKALNEJ DRODZE W PARKU KRAJOBRAZOWYM PUSZCZY KNYSZYŃSKIEJ}

\section{Streszczenie}

Przedmiotem badania $\mathrm{w}$ poniższej pracy była wiosenna migracja oraz śmiertelność dwóch pospolitych gatunków płazów na lokalnej drodze położonej na obszarze Parku Krajobrazowego Puszczy Knyszyńskiej w latach 2013-2015. Podczas trzech lat obserwacji, na badanym odcinku drogi stwierdzono 2745 osobników płazów należących do 7 gatunków amfifauny nizinnej oraz obecność kompleksu żab zielonych. Do najbardziej pospolitych gatunków płazów migrujących przez drogę do miejsc rozrodu należały: ropucha szara, traszka zwyczajna oraz żaba trawna.

Śmiertelność dwóch gatunków płazów (ropuchy szarej oraz żaby trawnej) spadła w trakcie 3 lat trwania obserwacji. Stwierdzono ponadto dodatnią korelację między temperaturą powietrza a liczbą migrujących przez drogę płazów.

Słowa kluczowe: płazy, migracja, śmiertelność na drodze, Polska, Park Krajobrazowy Puszczy Knyszyńskiej

Cite this article as: Arciszewski M. 2015. Migration of Amphibians and Their Mortality on the Road of Knyszyn Forest Landscape Park. Acta Biologica, 22: 5-14. 